\title{
Nigeria's Fiscal Performance: Exploring the Role of Exchange Rate
}

\author{
Fisayo Fagbemi \\ Independent Researcher, Nigeria \\ E-mail: fisay4real@yahoo.com \\ Olufemi Solomon Olatunde \\ Graduate student of the Department of Economics \\ Obafemi Awolowo University, Ile-Ife, Nigeria \\ E-mail: olufemi.olatunde@gmail.com
}

\begin{abstract}
The paper offers empirical justifications for the instrumentality of external sector in influencing the fiscal position of a country through the exchange rate. In the study, ARDL bounds test approach to cointegration analysis is adopted to examine the long run and short run relationship between exchange rate and fiscal performance in Nigeria. The validity of the findings is based on time series data between I98I and 2017. The emerging evidence reveals that the exchange rate movement has a substantial influence on the fiscal performance, as there exists a significant adverse relationship between exchange rate and fiscal deficit in the long run as well as in the short run, while the association between exchange rate and public debt is found to be significantly positive in both periods. Empirical elucidations posit that an appreciation of the exchange rate could lead to decreasing fiscal deficits. However, the exchange rate appreciation might not induce a reduction in public debt, as it could stimulate demand for loanable funds by the government, although such effect could be mitigated through strategic investment policy and subsidized funding schemes to aid domestic production. Given that fiscal performance is considerably driven or constrained by the exchange rate movement, the study suggests that developing a strategic framework for ensuring a realistic exchange rate and the mitigation of regular fluctuations or correcting inappropriate exchange rate is crucial.
\end{abstract}

Keywords: Exchange rate, Fiscal deficit, Public debt, Fiscal performance, ARDL, Nigeria.

\section{Introduction}

Over the years, the significant role of the exchange rate in any economy has been pretty uniform. Many economic analysts widely emphasize that macroeconomic aggregates (such as inflation rate, fiscal deficits and economic growth) often trend with the exchange rate movement (Bacha, I990; Miteza, 2006; Sek, Ooi, \& Ismail, 2012). Exchange rate, which is the price of the domestic currency in relation to foreign currencies, directly influences domestic price level, trading activities, allocation of resources, real income and investment decision. While an increasing divergence in exchange rates can create "a complex scheme of implicit subsidies and distorting national accounting," ensuring the stability of the exchange rates is critical for attaining substantial improvements in economic performance (Premium Times, 2018). The formidable bedrock of all macroeconomic variables is keeping the exchange rates stable. Hence, in most developing countries, including Nigeria, one of the most central measures of growth enhancement is the drive (policy initiatives) towards mitigating regular exchange rate fluctuations or correcting for its inappropriateness.

Following the weak state of Nigeria's economy between 1982 and 1985, various forms of floating regimes have been adopted since the introduction of the Structural Adjustment Programme (SAP) in I986. Compared to the fixed/pegged regimes of 1960s to mid-1980s, floating exchange rate has been viewed to have a considerable salutary influence due to the responsiveness of the rates to the foreign exchange market (Nwankwo, 1980). The persistent depreciation and instability of the Naira exchange rate (Figure I) necessitated the perennial efforts by the monetary authorities to stipulate the standard requirements for the economic and political conditions underpinning the structural evolution of the economy. Despite these policy stances, exchange rates have been frequently depreciating and unstable vis-à-vis the fledgling fiscal state, which has remained unabated. For instance, although slightly better than 2017 (2.8\%), Nigeria's consolidated fiscal balance recorded a deficit equal to $2.7 \%$ of its nominal GDP in Dec 2018, while Nigeria's National Government Debt stood at 63.3 billion (USD) in Mar 2018 (CEIC, 2018). 


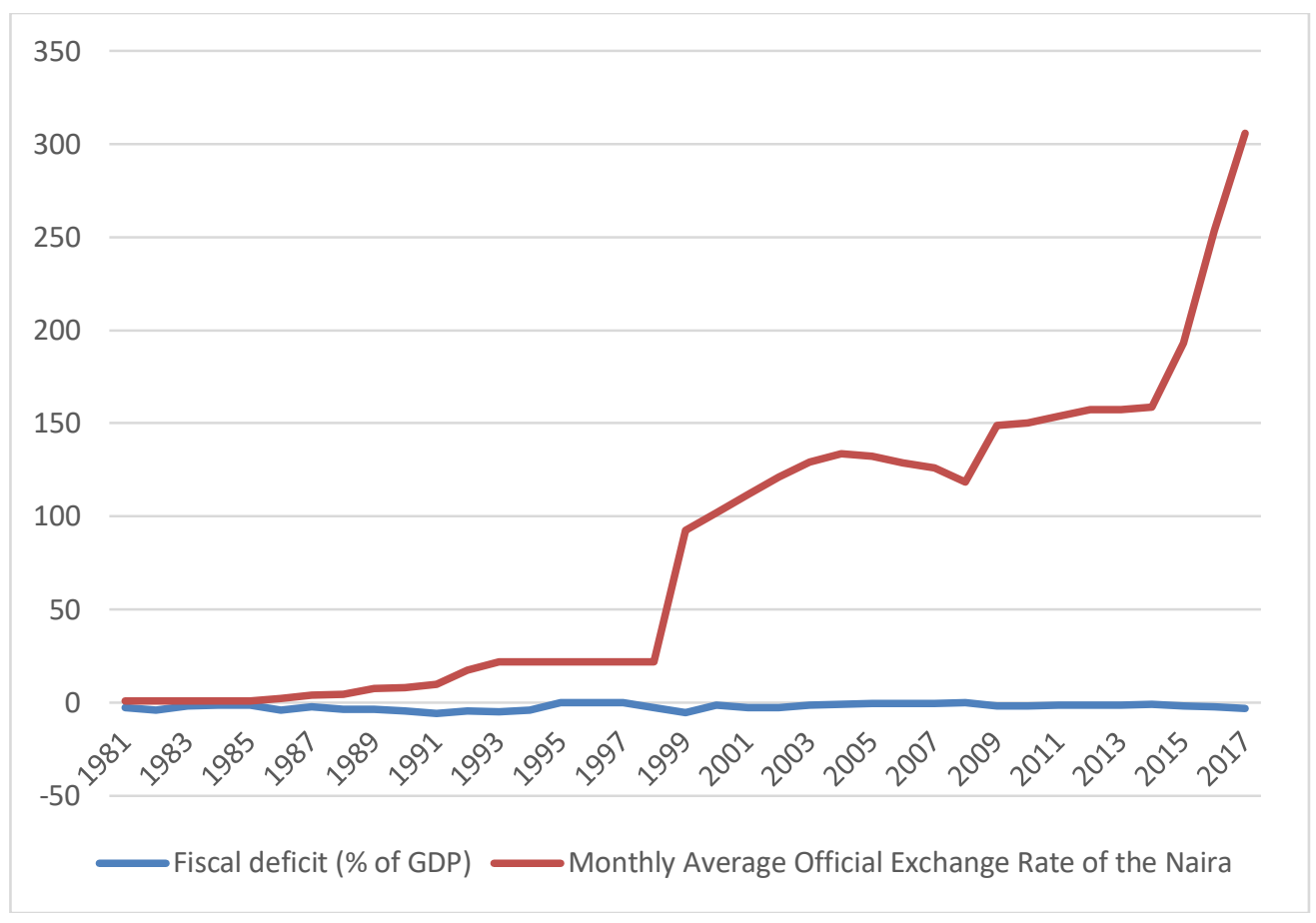

Figure I. Trend of Monthly Average Official Exchange Rate of the Naira and Fiscal deficit (\% of GDP)

Source: Authors' estimates based on data from Central Bank of Nigeria (CBN), 2018.

In 2017, Nigeria's fiscal deficit was put at 4.3\%. This deteriorating fiscal position has been mainly ascribed to the increased Eurobond issuances which has led to the growth in the public debt stock between the first half of 2017 and the first half of 2018 (Proshare, 2018). Accordingly, ensuing arguments have pointed to the substantial role exchange rate plays in most developing economies, as some scholars stressed that there exists a relationship between the exchange rate movements and macroeconomic aggregates (Hausmann, Pritchett, \& Rodrik, 2005; Rodrik, 2008). However, most of these studies center on the effect of exchange rate on economic growth, in spite of its potential influence on fiscal performance. Most studies on Nigeria also follow the same direction, as they largely espouse to the significance of floating exchange rate in the quest for sustainable growth (Akinlo \& Odusola, 2003; Asher, 2012; Obansa, Okoroafor, Aluko, \& Millicent, 20I3). Limited consideration given to the relationship between exchange rate and public sector performance has given rise to the growing uncertainty and agitation on the tenability of any veritable link between these economic indicators regarding Nigeria. In a nutshell, addressing the question as to whether Nigerian fiscal performance is considerably driven or constrained by the exchange rate movement is critical for ascertaining the possibility of fiscal modification through such effect.

The importance of sufficient empirical evidence on this crucial fiscal issue cannot be overemphasized. Hence, assessing the effect of exchange rate on fiscal performance exclusively in Nigeria's context is paramount to identify whether it substantially influences the country's fiscal position, which has been profoundly fundamental in public discourse. As a consequence, the study's main objective is to examine the long -run and short run relationship between exchange rate and fiscal deficits in Nigeria using auto-regressive distributed lag (ARDL) bounds test approach to cointegration analysis with a view to offering a reasonable framework for ensuring a realistic exchange rate that could enhance fiscal sustainability.

The rest of the paper is sectioned as follows: Section two centers on theoretical and empirical review. Section three deals with methodology. Section four contains the presentation and discussion of results, while the last section (five) gives the concluding remarks.

\section{Literature Review}

\section{ITheoretical Discussion}

Elucidations on the interplay between external sector and internal economic performance are based on divergent interrelated theories. For instance, Portfolio crowding -out hypothesis underscores the relationship between exchange rate and fiscal performance. This theory stresses that a huge budget deficit (public debt) incurred by the government will have direct effect on assets prices, and in turn lowers the level of aggregate demand in the economy (Friedman, 1978). On the other hand, in a clos ed 
economy, this hypothesis could mean a significant positive association between budget deficits and real interest rates. In Fleming (1962); Mundell (I96I) studies, both assert that in a flexible exchange rate regime system, a fiscal policy framework funded through a huge debt obligation is completely crowded-out in an open economy operating under static exchange rate expectation that is usually accompanied with fixed asset prices. In contrast, following Barro (1974), the taxpayers' expectation will usually alter the level of savings. This implies that if the taxpayers perceive that current deficits ought to be paid through future taxes, their savings will be increased by an amount equal to the current value of next generation (future) tax liabilities due to present deficits. $^{\mathrm{I}}$. In view of the branch linked to political issues, it is posited that given the inflationary implication for the fiscal authority, fiscal discipline can be better promoted by flexible regimes (Tornell \& Velasco, I994). The inter-temporal distribution of the costs associated with regimes often accounts for the difference in fiscal behavior.

Following the Balance of Payments restrained growth model, Thirlwall (I979) opines that the growth rate of any economy is constrained by the balance of Payments, as no country can grow faster than the consistent level of the Balance of Payments equilibrium, unless it can fund ever-increasing deficits, which is commonly perceived to be somewhat difficult. The model is anchored on the assumption that the long-term effect of export performance and import behavior on the economy shapes growth rate. Corroborating this assertion, Ferreira, Canuto, and Lima (2003) argue that the main components of aggregate demand are export growth and investment growth in import substitution, which have a positive influence on the growth of GDP, as well as to neutralize Balance of Payments constraints, The relevance of this model is linked to the role of export performance and import level in Balance of Payments and exchange rates. Hence, the significant effect on the economy, and in particular macroeconomic stability. However, the antagonist of the theory states that it fails to take into account the fiscal gap, savings-investment gap and monetary implication of the Balance of Payments (Darku, 20I3).

In another way, Calvo, Izquierdo, and Talvi (2003) posit that heavily dollarized countries in terms of liabilities can be wrecked by the disturbances associated with abrupt stops that mostly accompanied by a substantial rise in the real exchange rate. They argue that this could turn seemingly sustainable fiscal and corporate sector states into unsustainable positions. Also, according to Hausmann and Panizza (2003), balance sheets can be exposed to grave risks connected with a positive feedback between large real exchange rate depreciations and perceptions of public debt or deficits by the exchange rate mismatches linked with liability dollarization. On the contrary, the crux of the argument is that explicit government liabilities have been centered on the currency composition. The point of emphasis is on the increasing expected fiscal vulnerability of the state (country) following the presence of external currency denominated liabilities that gives rise to the cost of debt service or an adverse real shock resulting to a real depreciation.

\subsection{Empirical Evidence}

In the wake of fledgling fiscal state in most developing economies, there has been burgeoning interest in identifying the relationship between exchange rate and fiscal performance in countries. Many scholars have evaluated the cause of fiscal outcomes in diverse ways, yet probable inconsistencies in policy measures across economies. Empirical evidence indicates that external debt and exchange rate crises are strongly related in emerging economies (Guyot, Lagoarde-Segot, \& Neaime, 20I4; Neaime \& Gaysset, 2017; Neaime, Gaysset, \& Badra, 2018). These studies mainly center on the impact of public debt on exchange rate. On the other hand, expositions on the link between fiscal deficit and external sector are mixed. In the work of Piersanti (2000) using the Granger-Sims causality technique, while focusing on seventeen OECD countries over the period 1970-1997, indicates that external sector performance is adversely related with budget deficits. Studies that also support this line of argument are; Al-Khedair (1996); Islam (1998). However, based on the sample of developing countries with data between I950 and 1994, Khalid and Teo (I999), as measured by the current account deficit, establish that no relationship exists between fiscal deficit and external sector performance. Bachman (1992) findings are also consistent with this view. Further evidence on this mechanism remains unsettled (Kim \& Roubini, 2008; Ravn, Schmitt-Grohé, \& Uribe, 20I2).

The effect of real exchange rate on the aggregate output has been extensively explored. Mitchell and Pentecost (200I) using selected transition economies in the Central or Eastern European countries reveal that devaluations are contractionary in the long run as well as in the short run, while real appreciation could have a positive, adverse or neutral effect on output in different economies in the long run. In another study, devaluations are viewed to be contractionary in the long run (Miteza, 2006). On the contrary, Bahmani-Oskooee and Kutan (2008) posit that the effect of real depreciation on output may be contractionary, expansionary or neutral in different countries in the short run whereas it has no long-term effect on the level of output. Bahmani-Oskooee and Miteza (2003) stress that the net effect of real depreciation on aggregate output is somewhat uncertain depending on the countries under study, sample periods, methodology employed, model specifications, and other factors. With the adoption of a model wherein the relationship of foreign public debt with budget deficit, current account deficit and exchange rate depreciation is empirically explored for Debt Trap Countries (DTC) and Non Debt Trap Countries

I In the author's further study, the underlying literature draws from the Barro (I990) model, in essence, the optimal size of the State is determined by Barro such that public spending that maximizes the rate of economic growth. The issue of budget deficit allocated to public expenditure is not taken into account in the simple growth model. Thus, it is intuitively crucial to propose a model that incorporates foreign sector destined to enhance fiscal performance. 
(NDTC) of Asian pacific development countries, Alam and Taib (2013) reveal that external public debt are positively related with these variables. Nonetheless, in DTC and NDTC, the strength of the relationship varies. These studies focus on economies that have attributes that could be differed from Nigerian features. Thus, their findings might not be tenable in the country's context.

Working on the effect of exchange rate on debt, debt services and public debt management in Thailand, Patrawimolporn (2007), with the use of simple differentiation approach, shows that exchange rate volatility affects debt services. The author argument is premised on the assumption that a significant amount of debt services is saved when the exchange rate is adjusted. Regarding Nigeria, Ijeoma (2013), using linear regression model assesses the effect of debt variables (external debt stock and external debt service payment) on selected macroeconomic variables, including gross domestic product and gross capital formation. Findings confirm a significant association between Nigerian debt service payment and gross fixed capital formation, while exchange rate fluctuations have an influence on external debt shock, external debt service payment and economic growth. By and large, most studies on internal - external economic performance nexus center on the effect of fiscal policy shocks or public spending on real exchange rates and the trade balance. Basically, they focus on the response of the real exchange rate to government spending (Monacelli \& Perotti, 20I0; Kim, 2015; Auerbach \& Gorodnichenko, 2016).

More specifically, Ubok-udom (I999) examines the issues surrounding the implementation of SAP in Nigeria between I97I and 1995. The author posits that the efficacy of currency depreciation in producing desirable impacts is restricted by the peculiar features of Nigeria's economy. In another study, David, Umeh and Ameh (2010) assess the effect of exchange rate fluctuations on Nigerian manufacturing industry using multiple regression technique. They find an adverse correlation between exchange rate volatility and manufacturing sector performance. Other studies on Nigeria show that exchange rate has a strong influence on Gross Domestic Product (GDP) (Asher, 2012; Azeez, Kolapo \& Ajayi, 20I2; Obansa et al., 20I3). However, with the use of error correction model (ECM), Adebiyi and Dauda (2009) argue that trade liberalization does not promote the growth of the industrial sector in Nigeria, neither enhances the stability of the exchange rate market over the period of 1970 to 2006. Also, Lawal, Atunde, Ahmed, and Asaleye. (2016) using the Autoregressive Distributed Lag (ARDL) indicate that exchange rate fluctuations have no effect on economic growth in the long run between 2003 and 20I3. In light of these findings, systematic analysis on the effect of exchange rate on fiscal performance is limited in the context of Nigeria. Thus, this study is mainly driven by the scarcely reported empirical evidence coupled with the significance of offering comprehensive analysis essential for broadening the literature.

\section{Data and Methodology \\ 3.I Data}

Underscoring the significance of the study's objective, time series data spanning through I98I to 2017 are employed. The choice of scope is basically shaped by the drive to cover the floating exchange rate regimes in Nigeria. In the study, two fiscal indicators (as dependent variables) are used: fiscal deficit (\% of GDP) and public debt (\% of GDP). While fiscal deficit is defined as the excess of public spending over fiscal revenue, public debt represents the ratio of a country's public debt to its gross domestic product (GDP). Other variables (explanatory variables) used include: exchange rate, which is defined as the price of the domestic currency in relation to foreign currencies (in particular N/US\$I.00); inflation rate, consumer prices (annual \%), trade openness (the sum of exports and imports of goods and services measured as a share of GDP); and nominal GDP which represents the economic growth. Stemming from theoretical stance, in the process of linking exchange rate to fiscal performance , the inclusion of economic growth, inflation and trade openness are central (Thirlwall,1979; Tornell \& Velasco, I994; Miteza, 2006). The data for the study were obtained from Central Bank of Nigeria and National Bureau of Statistics (NBS) Statistical Bulletin (2018).

\subsection{Methodology}

Following the work of Bacha (I990); Mwega, Mwangi, and Olewe-Ochilo (I994) on the theoretical link between macroeconomic and fiscal variables, the functional relationship between exchange rate and fiscal performance is specified as:

$$
Z_{t}=f\left(E X H_{t}, G D P_{t}, I N F_{t} T R P_{t}\right)
$$

$Z$ represents fiscal performance (fiscal deficits and public debt) where $t$ is the time period. EXHindicates the exchange rate. Economic growth is represented by GDP. INF is defined as the inflation, while trade openness is given as TRP.

With a view to avoid the problem of reverse causality and non-stationarity of variables, Autoregressive Distributed Lag (ARDL) model which is a dynamic framework is adopted. The key significance of this approach is that it can simultaneously account for long run and short run relationship within the same framework irrespective of the order of integration of the variables, that is, whether there is combination of $\mathrm{I}(\mathrm{I})$ and $\mathrm{I}(0)$ or variables are $\mathrm{I}(\mathrm{I})$ or $\mathrm{I}(0)$. Moreover, the adoption of ARDL technique is influenced by its advantage over other estimation methods such as Engle and Granger (I987); Johansen and Juselius 
(I990); Johansen (I99I); Gregory and Hansen (1996) that are mainly applicable when the variables in the model are of the same order of integration, besides their requirement for large data size for ensuring the validity and robustness of results. Overall, ARDL procedure is suitable for small sample size, which implies that it can circumvent the problem of biasness that often arises from small sample size (Pesaran \& Shin, 1997; Narayan, 2005). Hence, the ARDL model for the study is stated as:

$$
\begin{gathered}
\Delta \ln Z_{t}=\delta_{o}+\sum_{i=1}^{p} \delta_{1} \Delta \ln Z_{t-i}+\sum_{i=0}^{p} \delta_{2} \Delta E X H_{t-i}+\sum_{i=0}^{p} \delta_{3} \Delta \ln G D P_{t-i}+\sum_{i=0}^{p} \delta_{4} \Delta I N F_{t-i}+\sum_{i=0}^{p} \delta_{5} \Delta \ln T R P_{t-i} \\
+\theta_{1} \ln Z_{t-1}+\theta_{2} E X H_{t-1}+\theta_{3} \ln G D P_{t-1}+\theta_{4} I N F_{t-1} \theta_{5} \ln T R P_{t-1}+\mu_{t}
\end{gathered}
$$

The $\log$ of the variables is represented by $\ln . \mu$ is the white noise error while $\Delta$ is defined as the difference operator.

The cointegration relationship between the dependent variable $(\boldsymbol{Z})$ and the explanatory variables can be traced by placing restriction on all estimated parameters of lagged level variables to be equal to zero. That is, null hypothesis; $H_{o}: \theta_{i}=0$ (where $i=\mathrm{I}, 2, \ldots \ldots, 5$ ), against the alternative hypothesis: $H_{1}: \theta_{i} \neq 0$. In this case, the null hypothesis implies that there is no long run relationship among the variables, whereas the alternative hypothesis states that there is existence of long run relationship among the variables.

Decision rule: if the computed F - statistics is less than lower bound critical value, we do not reject the null hypothesis of no integration. But the null hypothesis is rejected, if computed F - statistics is greater than upper bound critical value; indicating that steady state equilibrium is said to exist among the estimated variables. However, if the computed value falls within the bound, the decision will be termed inconclusive. When there is presence of long run relationship among the variables, error correction representation is established (Pesaran, Shin, \& Smith, 200I). Hence, the Eq. (2) in the ARDL form of the error correction model can be stated as:

$$
\begin{gathered}
\Delta \ln Z_{t}=\delta_{o}+\sum_{i=1}^{p} \delta_{1} \Delta \ln Z_{t-i}+\sum_{i=0}^{p} \delta_{2} \Delta E X H_{t-i}+\sum_{i=0}^{p} \delta_{3} \Delta \ln G D P_{t-i}+\sum_{i=0}^{p} \delta_{4} \Delta I N F_{t-i}+\sum_{i=0}^{p} \delta_{5} \Delta \ln T R P_{t-i} \\
+\gamma E R_{t-1}+\mu_{t}
\end{gathered}
$$

Where $E R$ represents the residuals that obtained from estimated Eq. (2), while $\gamma$ is the speed of adjustment parameter. The parameter of error correction term $(E R)$ in the model, after a short-run shock, implies the speed of adjustment back to long-run equilibrium.

\section{Empirical Results and Discussion}

It is worth mentioning that both Augmented Dickey Fuller (ADF) and Phillip Peron (PP) are applied to ascertain the level of stationarity of the series. In Table I, the results presented reveal that none of the estimated variables is found to be $\mathrm{I}(2)$ or above. The order of integration is confirmed to be I (0) and I (I). This implies that Autoregressive Distributed Lag (ARDL) model is mostly applicable in this study. Thus, the computed F-statistic, based on Pesaran et al. (200I), is compared with upper and lower critical bounds as presented in Table 2. Accordingly, the null hypothesis of no cointegration with clear specification was rejected at I\% significant level in both models - (i) \& (ii). The stability of the models is tested through Cumulative Sum of Recursive Residuals (CUSUM) and Cumulative Sum of Squares of Recursive Residuals (CUSUMSQ). In Figure 2, the test establishes that in each model, the ARDL model parameters are stable, as CUSUM and CUSUMSQ lie within the critical boundaries. Other tests (diagnostic tests) were also checked for in order to ensure that the results obtained are valid and robust.

\begin{tabular}{|c|c|c|c|c|}
\hline \multirow[t]{2}{*}{ Variable } & \multicolumn{2}{|c|}{ Augmented Dickey Fuller } & \multicolumn{2}{|c|}{ Phillips-Perron } \\
\hline & Level & First difference & Level & First difference \\
\hline Fiscal deficit & $-2.92(0)^{2 x}$ & $-3.38(2)^{2}$ & $\begin{array}{l}- \\
2.99^{\prime 2 x y}\end{array}$ & $-8.26^{2}$ \\
\hline Public debt & $-1.22(\mathrm{I})$ & $-4.54(0)^{2}$ & -1.62 & 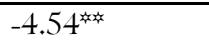 \\
\hline Exchange rate & $1.28(\mathrm{I})$ & $-3.30(0)^{2}$ & 1.83 & $-3.30^{2 x y}$ \\
\hline GDP & $-0.79(0)$ & $-3.15(0)^{2}$ & -0.64 & $-3.07^{x}$ \\
\hline
\end{tabular}
In the study, model (i) represents the inclusion of fiscal deficit as fiscal performance indicator, whereas model (ii) is taken for public debt.

Table I. Augmented Dickey Fuller (ADF) and Phillips-Perron (PP) unit root test results 


\begin{tabular}{|c|c|c|c|c|}
\hline Inflation & $-2.85(0)^{2 . x}$ & $-3.7 \mathrm{I}(3)^{x}$ & -2.73 & $-9.40^{2}$ \\
\hline Trade openness & $-2.06(2)$ & $-6.19(0)^{2}$ & -1.26 & $-6.23^{x}$ \\
\hline
\end{tabular}

represent lag length selected by AIC criterion. The PP length was selected by Newey-West Band Width.

Table 2. Bounds F-tests for cointegration relationship

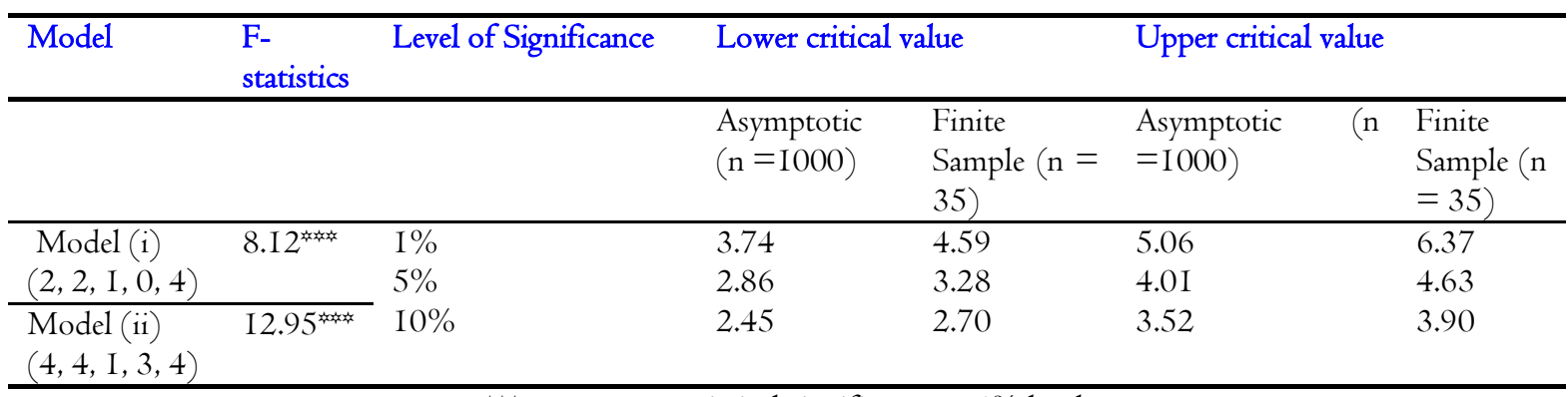

represents statistical significance at $\mathrm{I} \%$ level.

Beginning with the main variable of interest, in Table 3, exchange rate is statistically significant and adversely related to fiscal deficits, suggesting that exchange rate has a strong influence on fiscal performance. The adverse relationship between exchange rate and fiscal deficits could mean that an appreciation of the domestic currency against the foreign currencies would lead to decreasing fiscal deficits, and thus strengthens the fiscal position in the long run. This relationship holds in the short run as well in the same model (i). The empirical postulation that macroeconomic aggregates (including fiscal performance) often trend with exchange rate movement is consolidated by these findings (Bacha, 1990; Sek et al., 20I2). On the other hand, an appreciation of the exchange rate may not lead to a reduction in public debt, as exchange rate is found to be positively and significantly associated with public debt in the long run as well in the short run in model (ii). A plausible explanation for these findings is that when the exchange rate appreciates, it will cause the demand for the country's produce (exports) in abroad to fall as they become more expensive in foreign countries. This could lead to a decrease in fiscal revenue. Hence, the government would need to borrow more to run its budget, which might turn seemingly sustainable fiscal and corporate sector states into unsustainable positions. In contrast, a weaker exchange rate may cause the demand for loanable funds to reduce. These expositions are in line with the assertion of Calvo et al. (2003); Hausmann and Panizza (2003). Regarding the effect of the economic growth, GDP is significant in the long run as well as in the short run in model (i), but it is only significant in the short run in model (ii). The insignificance in this context could be warranted by the constrained effect of pervasive injudicious use of economic resources in the public sector. Decreasing fiscal deficits and public debt reduction could be better enhanced when a sustained increase in GDP is properly channeled and efficiently utilized (Proshare, 2018). Moreover, in model (i) \& (ii), the estimated parameters of inflation are positive and significant in the long run as well in the short run. These results marry up with the conjecture that high inflation usually increases the size of public spending, and in turn undermines the likelihood of reducing fiscal deficits (Talvi \& Vegh, 2005). On the effect of trade openness, the estimated coefficients are significant in both long run and short run, but only significant in the short run in model (ii). This endorses the relevance of a liberal trade regime to enhance fiscal performance. Nonetheless, compared to import, the low level of export could account for the insignificance in the long run. It points to the fact that overdependence on import vis-à-vis weak domestic production may lead to sustained shortfalls in fiscal revenue, and as a consequence, poor fiscal performance.

Table 3. ARDL long run and short run estimates

\begin{tabular}{|c|c|c|c|c|}
\hline Variable & $\begin{array}{l}\text { Fiscal defici } \\
\text { Model (i) }\end{array}$ & & $\begin{array}{l}\text { Public debt } \\
\text { Model (ii) }\end{array}$ & \\
\hline & Long run & Short run & Long run & Short run \\
\hline Constant & & $\begin{array}{l}-3.74^{\text {xyx }} \\
{[-5.06]}\end{array}$ & & $\begin{array}{l}1.60^{x+x} \\
{[3.00]}\end{array}$ \\
\hline Exchange rate & $\begin{array}{l}-0.09^{2} \\
{[-2.43]}\end{array}$ & $\begin{array}{l}-0.04^{2} \\
{[-5.37]}\end{array}$ & $\begin{array}{l}0.06^{\text {ax }} \\
{[2.25]}\end{array}$ & $\begin{array}{l}0.0 \mathrm{I}^{2} \\
{[5.87]}\end{array}$ \\
\hline GDP & $\begin{array}{l}\text { I0.92 } \\
{[2.44]}\end{array}$ & $\begin{array}{l}\text { I2.I I } \\
{[6.38]}\end{array}$ & $\begin{array}{l}-10.20 \\
{[-1.14]}\end{array}$ & $\begin{array}{l}-3.899 \\
{[-3.09]}\end{array}$ \\
\hline
\end{tabular}




\begin{tabular}{|c|c|c|c|c|}
\hline Inflation & $\begin{array}{l}0.10^{* 2 x} \\
{[2.14]}\end{array}$ & $\begin{array}{l}0.2 \mathrm{I}^{2} \\
{[\mathrm{I} .80]}\end{array}$ & $\begin{array}{l}0.15^{\text {क }} \\
{[1.73]}\end{array}$ & $\begin{array}{l}0.02^{\text {that }} \\
{[2.65]}\end{array}$ \\
\hline Trade openness & $\begin{array}{l}-6.42 \\
{[-2.23]}\end{array}$ & $\begin{array}{l}0.70^{\text {;x }} \\
{[1.88]}\end{array}$ & $\begin{array}{l}8.23 \\
{[1.25]}\end{array}$ & $\begin{array}{l}0.66^{\text {ax }} \\
{[3.40]}\end{array}$ \\
\hline $\operatorname{ER}(-\mathrm{I})$ & & $\begin{array}{l}-0.39 \\
{[-4.89]}\end{array}$ & & $\begin{array}{l}-0.3 I \\
{[-12.93]}\end{array}$ \\
\hline \multicolumn{5}{|l|}{ Diagnostic Tests } \\
\hline D.W & 2.03 & & 2.15 & \\
\hline Ramsey reset test & 0.12 & & 0.84 & \\
\hline Normality test & 0.20 & & 0.19 & \\
\hline Serial correlation & 0.25 & & 0.72 & \\
\hline
\end{tabular}

* indicate statistical significance at I0\%, 5\% and I\% respectively, whilst figures in (-) are t-values.

Furthermore, the estimated parameters of the Error Correction Term $\left(E R_{t-1}\right)$ depict the speed of adjustment of fiscal performance to shocks in exogenous variables across models. The negative sign and statistical significance of the estimated coefficients of Error Correction Term (ECT), in both model (i) \& (ii), imply a stable process of adjustment to the long run equilibrium, and the respective values of the estimates confirm the validity of the error-correction term $\left(E R_{t-1}\right)$. In general, ARDL procedure demonstrates that exchange rate has a strong effect on Nigerian fiscal performance. It is noted that the country's fiscal position is vulnerable to exchange rate movement. The divergence in exchange rates could constrain fiscal measures, and thereby engendering resistance to the development of sustainable fiscal position.

Model (i) - Fiscal deficit
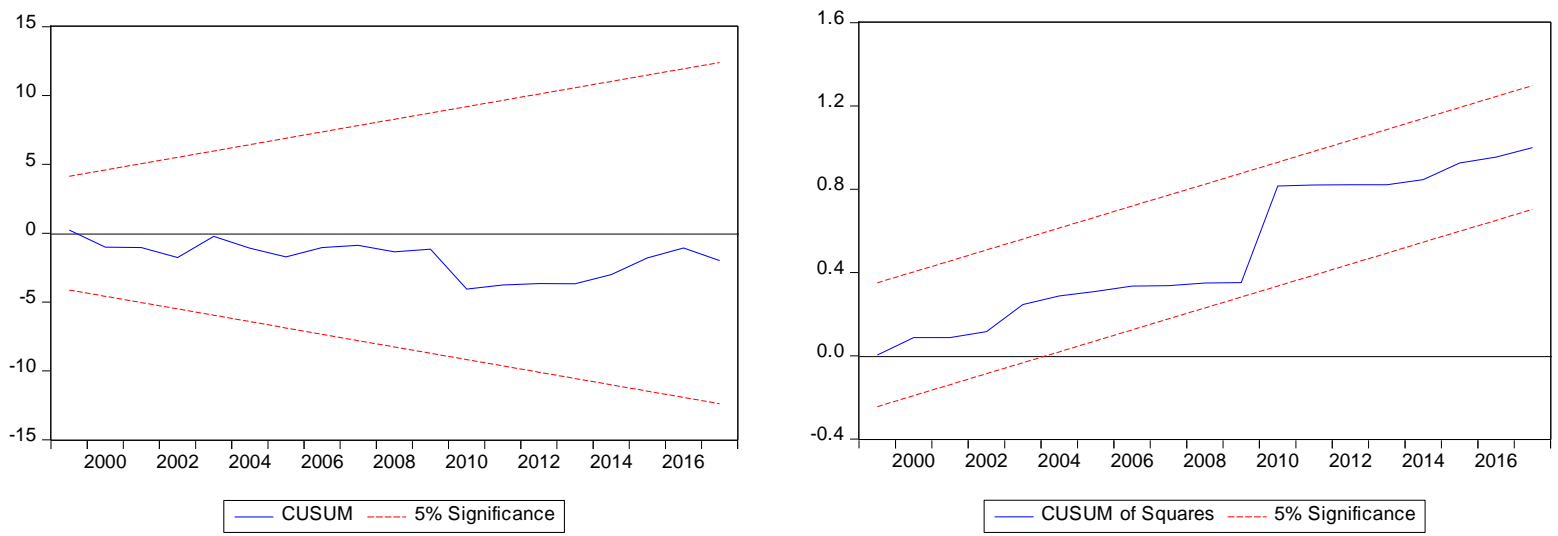

Model (ii) — Public debt
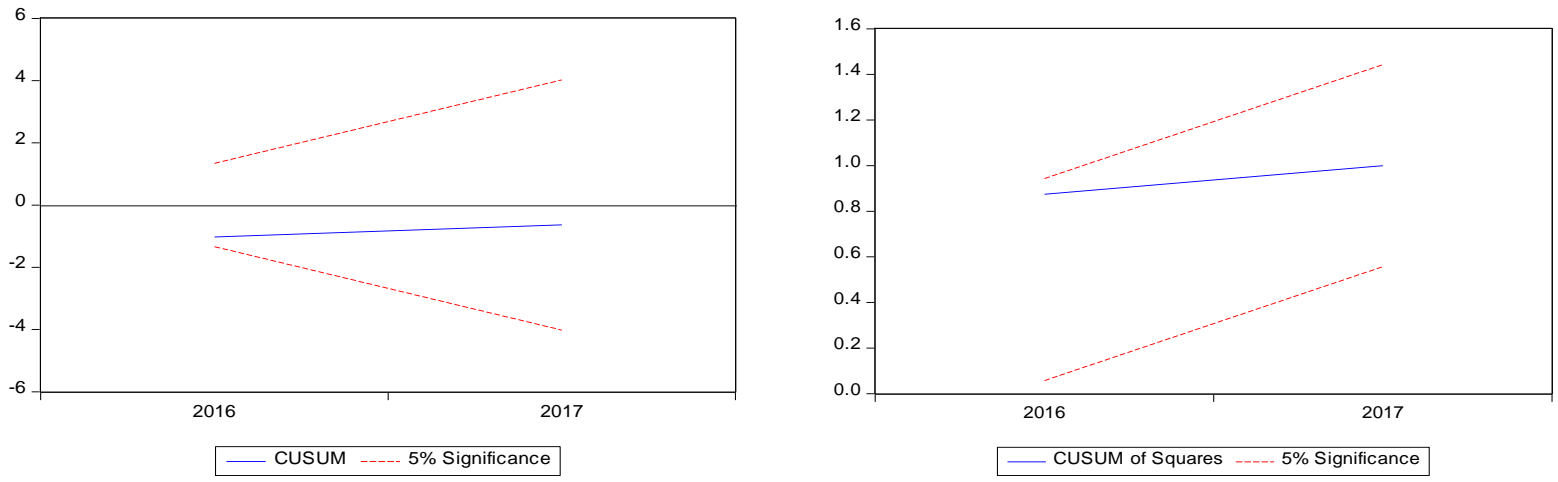

Figure 2. Cusum (Left) \& Cusumsq (Right) 


\section{Concluding Remarks}

The paper offers empirical justifications for the instrumentality of external sector in influencing the fiscal position of a country through the exchange rate. In the study, ARDL procedure is adopted to examine the long run and short run relationship between exchange rate and fiscal performance in Nigeria. The validity of the findings is based on time series data between I98I and 2017. Given the main goal of the study, two fiscal measures are employed (fiscal deficit and public debt). The analysis is conducted with the use of different models on the respective fiscal indicators to ensure the validity and robustness of results or outcomes across specifications and in consistence with the theoretical postulations.

The emerging evidence arising from the findings reveals that, in Nigeria's context, the exchange rate movement has a substantial influence on the fiscal performance. The key conclusion reached is that there exists a significant adverse relationship between exchange rate and fiscal deficit in the long run as well as in short run, while the association between exchange rate and public debt is found to be significantly positive in both periods. The empirical elucidations suggest that an appreciation of the exchange rate could result to decreasing fiscal deficits, and thus engenders improved fiscal position in the long run. However, the exchange rate appreciation might not induce a reduction in public debt, as such could lead to a significant decrease in demand for the country's produce (exports) in abroad. This may have negative effect on the fiscal revenue, and in turn stimulates demand for loanable funds by the government, although such effect could be mitigated through strategic investment policy and subsidized funding schemes to boost domestic production.

In a nutshell, further evidence posits that decreasing fiscal deficits and public debt reduction could be better enhanced when a sustained increase in GDP is properly channeled and judiciously utilized. On the other hand, continued overdependence on import vis-à-vis weak domestic production may lead to sustained shortfalls in fiscal revenue, and thus undermines fiscal performance potential. Following the assertion that fiscal performance is considerably driven or constrained by the exchange rate movement, developing a strategic framework for ensuring a realistic exchange rate and the mitigation of regular fluctuations or correcting inappropriate exchange rate is crucial.

\section{References}

Adebiyi, M.A \& Dauda, R.O. (2009). Trade liberalization policy and industrialization growth performance in Nigeria: An error correction mechanism technique. Being a paper presented at the 45th annual conference of the Nigerian economic Society, 24th to 26th August, Central Bank of Nigeria new building auditorium. Abuja.

A. E. Akinlo \& Odusola, A.F. (2003). Assessing the impact of Nigeria's naira depreciation on output and inflation. Applied Economics, Taylor \& Francis Journals, 35(6), 69I-703.

Alam, N. \& Taib, F. (2013). An investigation of the relationship of external public debt with budget deficit, current account deficit and exchange rate depreciation in debt trap and non-debt trap countries. European Scientific Journal, 9(22), I44-I58.

Al-Khedair, S. I. (1996). The impact of the budget deficit on key macroeconomic variables in the major industrial countries. Ph.D. Dissertation, Florida Atlantic University.

Asher O.J. (2012). The impact of exchange rate fluctuation on the Nigeria economic growth (I980 - 20I0). Unpublished B.sc Thesis of Caritas University Emene, Enugu State, Nigeria.

Auerbach, A. J. \& Gorodnichenko, Y. (2016). Effects of fiscal shocks in a globalized world. IMF Economic Review, 64(I), I77-2I5.

Azeez, B.A., Kolapo, F.T. \& Ajayi, L.B. (2012). Effect of exchange rate volatility on macroeconomic performance in Nigeria. Interdisciplinary Journal of Contemporary Research in Business, 4(I), I49-I55.

Bacha E. L. (1990). A three-gap model of foreign transfers and the GDP growth rate in developing countries. Journal of Development Economies, 32(2), 19-35.

Bachman, D.D. (1992). Why is the US current account deficit so large? Evidence from vector autoregressions. Southern Economic Joumal, 59(2), 232-40.

Bahmani-Oskooee, M. \& Kutan, A.M. (2008). Are devaluations contractionary in emerging economies of Eastern Europe? Economic Change and Restructuring, 4I, 6I-74.

Bahmani-Oskooee, M. \& Miteza, I. (2003). Are devaluations expansionary or contractionary? A Survey Article. Economic Issues, 8(2), I-28.

Barro, R. J., (1990). Government spending in a simple model of endogenous growth. Journal of Political Economy, 98(5), I03-I25.

Barro, R.J. (1974). Are government bonds net wealth? Journal of Political Economy, 82(6), I095-I I 7.

Calvo, G. A., Izquierdo, A. \& Talvi, E. (2003). Sudden stops, the real exchange rate, and fiscal sustainability: Argentina's lesson. NBER Working Paper No. 9828.

CEIC (2018). Global economic data, indicators, Charts \& Forecasts. CEIC.

Darku, C. (2013). The report: Ghana 2013. Oxford Business Group https://books.google.com.ng/books?isbn=I90706589X. 
David, U. \& Ameh, A. (2010). The Effect of exchange rate fluctuations on Nigeria manufacturing sector. African Journal of Business Management, 4(I4), 2994-2998.

Engle, R.F. \& Granger, C.J. (1987). Cointegration and error-correction-representation, estimation and testing. Econometrica, 55, 25I-278.

Ferreira, A.L., Canuto, O. \& Lima, G.T. (2003). Thirlwall's law and foreign capital in Brazil. Momento Economico, JanuaryFebruary, 125, 18-29.

Fleming, J.M. (1962). Domestic financial policies under fixed and under floating exchange rates. Staff Papers (International Monetary Fund), 9(3), 369-380.

Gregory, A.W. \& Hansen, B.E. (1996). Tests for cointegration in models with regime and trend shifts. Oxford Bulletin of Economics and Statistics, 58, 555-560.

Guyot, A., Lagoarde-Segot, T. \& Neaime, S. (20I4). Foreign shocks and international cost of equity destabilization: Evidence from the MENA region. Emerging Markets Review, I8, I0I-22.

Hausmann, R. \& Panizza, U. (2002). The mystery of original sin. Mimeo Kennedy School of Government.

Hausmann, R., Pritchett, L. \& Rodrik, D. (2005). Growth Accelerations. Journal of Economic Growth, IO(4), 303-29.

Ijeoma, N.B. (2013). An empirical analysis of the impact of debt on the Nigerian economy. International Journal of Arts and Humanities, 2(7), I65-19I.

Islam, M.F. (1998). Brazil's twin deficits: An empirical examination. Atlantic Economic Journal, 26 (2):I2 I - I28.

Johansen, S. (I99I). Estimation and hypothesis testing of co-integration vectors in Gaussian vector autoregressive models. Econometrica, 59, I55I - I580.

Johansen, S. \& Juselius, K. (I990). Maximum likelihood estimation and inference on cointegration with application to the demand for money. Oxford Bulletin of Economics and Statistics, 52, 169 - 210.

Khalid, A. M. \& Teo, G.W. (I999). Causality tests of budget and current account deficits: Cross-country comparisons. Empirical Economics, 24 (3), 389-402.

Kim, S. (20I5). Country characteristics and the effects of government consumption shocks on the current account and real exchange rate. Journal of International Economics, 97(2), 436-447.

Kim, S. \& Roubini, N. (2008). Twin deficit or twin divergence? Fiscal policy, current account, and real exchange rate in the U.S. Journal of International Economics, 74(2), 362-383.

Lawal A. I., Atunde, I.O., Ahmed, V. \& Asaleye, A. (2016). Exchange rate fluctuation and the Nigeria economic growth. EuroEconomica, 35 (2): I24 - I38.

Mitchell, A., \& Pentecost, E.J. (200I). The Real Exchange Rate and the Output Response in Four Transition Economies: A Panel Data Study. In Exchange Rate Policies, Prices and Supply-Side Response. Edited by C. Papazoglou and E. J. Pentecost, 68-77. Houndmills: Palgrave Macmillan.

Miteza, I. (2006). Devaluation and output in five transition economies: A panel cointegration approach of Poland, Hungary, Czech Republic, Slovakia and Romania, 1993-2000. Applied Econometrics and International Development, 6, 7786.

Monacelli, T. \& Perotti, R. (20I0). Fiscal policy, the real exchange rate and traded goods. Economic Journal, I20 (544), 437$46 \mathrm{I}$.

Mundell, R.A. (I96I). A theory of optimal currency areas. American Economic Review, 5I, 509-5I7.

Mwega F.M., Mwangi, N. \& Olewe-Ochilo, F. (I994). Macroeconomic constraints and medium-term growth in Kenya: A three-gap analysis. African Joumal of Economic Policy, I (3), I I0-I I5.

Narayan, P. (2005). The saving and investment nexus for China: Evidence from co-integration tests. Applied Economics, 37, I979-1990.

Neaime, S. \& Gaysset, I. (2017). Sustainability of macroeconomic policies in selected MENA countries: Post financial and debt crises. Research in International Business and Finance, 40(C):129-I40.

Neaime, S., Gaysset, I. \& Badra, N. (2018). The Eurozone debt crisis: A Structural VAR Approach. Research in International Business and Finance, 43, 22-33.

Nwankwo, G. O. (1980). The Nigerian financial system. London: Macmillan; New York: Africana Pub. Co. [distributor], I980, https://trove.nla.gov.au/version/30475303.

Obansa, S.A., Okoroafor, O.D., Aluko, O.O. \& Millicent, E. (2013). Perceived relationship between exchange rate, interest rate and economic growth in Nigeria: 1970-2010. American Joumal of Humanities and Social Sciences, I(3), II6-I24.

Patrawimolporn, P. (2007). Effect of exchange rate on debt, debt services and public debt management in Thailand in the I980s. Asian Economic Journal, 5(3), 339-355.

Pesaran, H. \& Shin, Y. (1997). An autoregressive distributed lag modeling approach to co-integration analysis. University of Cambridge, England. 
Pesaran, M. H., Shin, Y. \& Smith, R.J. (200I). Bounds testing approaches to the analysis of level relationships. Journal of Applied Econometrics, 16, 289-326.

Piersanti (2000). Impact of the budget deficit on key macroeconomic variables in the major industrial countries. The Florida Atlantic University Libraries.

Premium Times (2018). Nigeria's fiscal deficit may widen in 20I8 - World Bank. Premium Times (November 26, 2018)

Proshare (2018). Driving effective fiscal spending in Nigeria as a part of fiscal consolidation. Proshare Economy (August I7, 2018).

Ravn, M. O., Schmitt-Grohé, S. \& Uribe, M. (2012). Consumption, government spending, and the real exchange rate. Journal of Monetary Economics, 59(3), 215-234.

Rodrik, D. (2008). The real exchange rate and economic growth. Brookings papers on economic activity, 39 (2):365-439.

Sek, S. K., Ooi, C.P. \& Ismail, M.T. (2012). Investigating the relationship between exchange rate and inflation targeting. Applied Mathematical Sciences, 6(32), I57I-I583.

Thirlwall, A. P. (1979). The balance of payments constraint as an explanation of international growth rate differences. Banca Nazionale del Lavoro Quarterly Review, 32(128), 45-53.

Tornell, A. Y. \& Velasco, A. (1994). Fiscal policy and the choice of exchange rate regime. Inter-American Development Bank working paper No.303.

Ubok-Udom, E.U. (1999). Currency depreciation and domestic output growth in Nigeria: I97I-I995. The Nigerian Journal of Economics and Social studies, 4I(I), 3I-44.

\section{Copyrights}

Copyright for this article is retained by the author(s), with first publication rights granted to the journal. This is an open-access article distributed under the terms and conditions of the Creative Commons Attribution license (http://creativecommons.org/licenses/by/4.0/). 